\title{
Campo Belo Metamorphic Complex: Tectonic Evolution of an Archean sialic crust of the southern São Francisco Craton in Minas Gerais (Brazil)
}

\author{
ARILDO H. OLIVEIRA and MAURÍCIO A. CARNEIRO \\ Departamento de Geologia da Escola de Minas da Universidade Federal de Ouro Preto \\ (DEGEO/EM/UFOP), Morro do Cruzeiro/Campus Universitário \\ Manuscript received on August 30, 2000; accepted for publication on April 17, 2001; \\ presented by WILSON TEIXEIRA
}

\begin{abstract}
Systematic geological studies performed in the study area allowed the characterization of six lithodemic units: three gneissic, one amphibolitic, one supracrustal and one fissure mafic. The mineral assemblage and the structural record of these lithodemic units indicate that the study area was affected by five tectonothermal events. The structural pattern of the first and oldest event occurred under granulite facies conditions and reveals essentially a sinistral kinematic pattern. The second event, showing dominant extensional characteristics, is related to the generation of an ensialic basin filled by the volcano-sedimentary sequence of the supracrustal lithodemic unit. The third event, which is the most expressive in the study region, is characterized by a vigorous regional migmatization process and by the generation of the Claudio Shear Zone, presenting dextral kinematic movement. The fourth event is represented by a fissure mafic magmatism (probably two different mafic dike swarms) and finally, the fifth event is a regional metamorphic re-equilibration that reached the greenschist facies, closing the main processes of the tectonic evolution of the Campo Belo Metamorphic Complex.
\end{abstract}

Key words: Craton, Archean, tectonic evolution, lithodemic units, metamorphic complex.

\section{INTRODUCTION}

The São Francisco Craton is a vast Precambrian platform (Alkmim et al. 1993, Almeida 1977), which encompasses part of Minas Gerais and Bahia States (Fig. 1). Its southern portion (Fig. 1) presents significant expositions of Neoarchean granite-greenstone terranes; its tectonic evolution started in the Mesoarchean (Carneiro et al. 1998a, Teixeira et al. 1996a, Teixeira et al. 1998). From that period on the first sialic crusts and supracrustal sequences were generated by means of successive accretion/

Correspondence to: Maurício Antônio Carneiro

E-mail: mauricio@degeo.ufop.br / aholiver@degeo.ufop.br differentiation stages associated with crustal reworking processes (Carneiro et al. 1996a, Carneiro et al. 1997a,b, Carneiro et al. 1998a,b, Noce 1995, Pinese 1997, Teixeira 1993, Teixeira and Silva 1993, Teixeira and Canzian 1994, Teixeira et al. 1996a,b, Teixeira et al. 1997, Teixeira et al. 1999).

The apex of these processes took place in the Neoarchean, during the Rio das Velhas Tectonothermal Event (Carneiro et al. 1998a). Other events are also represented in this crustal segment. They are: two events of tectonothermal nature in the Mesoarchean [3.2 and 2.9 Ga, (Teixeira et al. 1996a, Teixeira et al. 1998)]; a migmatization event [2.86 


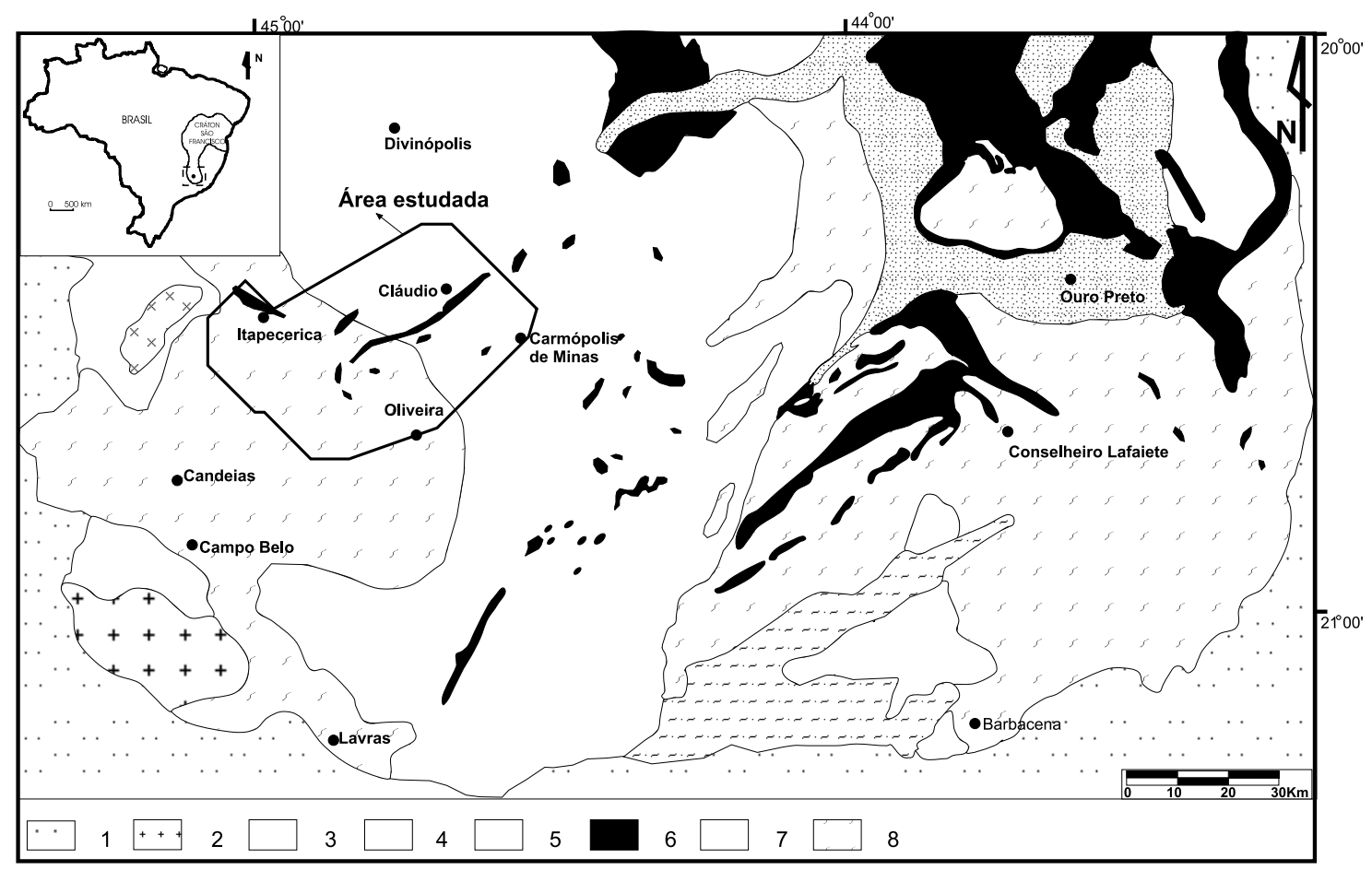

Fig. 1 - Geologic map of southern São Francisco Craton (modified from Machado Filho et al. 1983). 1) Undivided marginal belts; 2) Porto dos Mendes Granite; 3) São João del Rey Supergroup; 4) Minas Supergroup; 5) Formiga Granite; 6) Rio das Velhas Supergroup; 7) Divinópolis Metamorphic Complex, and 8) Barbacena Metamorphic Complex.

Ga, (Noce 1995)]; a fissure mafic magmatism event [2.658 Ga, (Pinese 1997)] and a felsic magmatism event [2.65 Ga, (Noce 1995)]. Due to this succession of events, the tectonic relationships between the generated (or reworked) units were progressively masked. Therefore, a complex structural pattern was imprinted in the lithodemic units that constitute the metamorphic complex, their supracrustal sequences and intrusive bodies that crop out in the study area. Recent research, involving regional $(1: 200,000)$ and detailed $(1: 10,000)$ mapping performed in the Campo Belo, Oliveira, Itapecerica, Cláudio, Carmópolis de Minas regions has characterized new lithodemic units and presented new facts to the tectonic evolution of the southern São Francisco Craton (Carneiro et al. 1996a,b, Carneiro et al. 1997a,b,c, Carneiro et al. 1998a,b, Carvalho Júnior et al. 1997, Carvalho Júnior et al. 1998,
Corrêa da Costa et al. 1998, Corrêa da Costa 1999, Fernandes et al. 1997, Fernandes et al. 1998, Fernandes and Carneiro 2001, Oliveira et al. 1998a,b, Oliveira 1999, Oliveira and Carneiro 1999, Oliveira et al 1999). In this work the results of one of these studies (Oliveira 1999) are presented, carried out in the Cláudio, Itapecerica, São Francisco de Paula, Oliveira and Carmópolis de Minas region, involving lithostructural mapping at the 1:200,000 scale (Figs. 1 and 2).

\section{GEOLOGIC CONTEXT}

The sialic crust of the southern São Francisco Craton is constituted by gneisses, granitoids, amphibolites, mafic and ultramafic rocks, schists and quartzites that were grouped by Machado Filho et al. (1983), in the Divinópolis and Barbacena metamorphic complexes (Fig. 1). Locally, remains of the supracrustal 


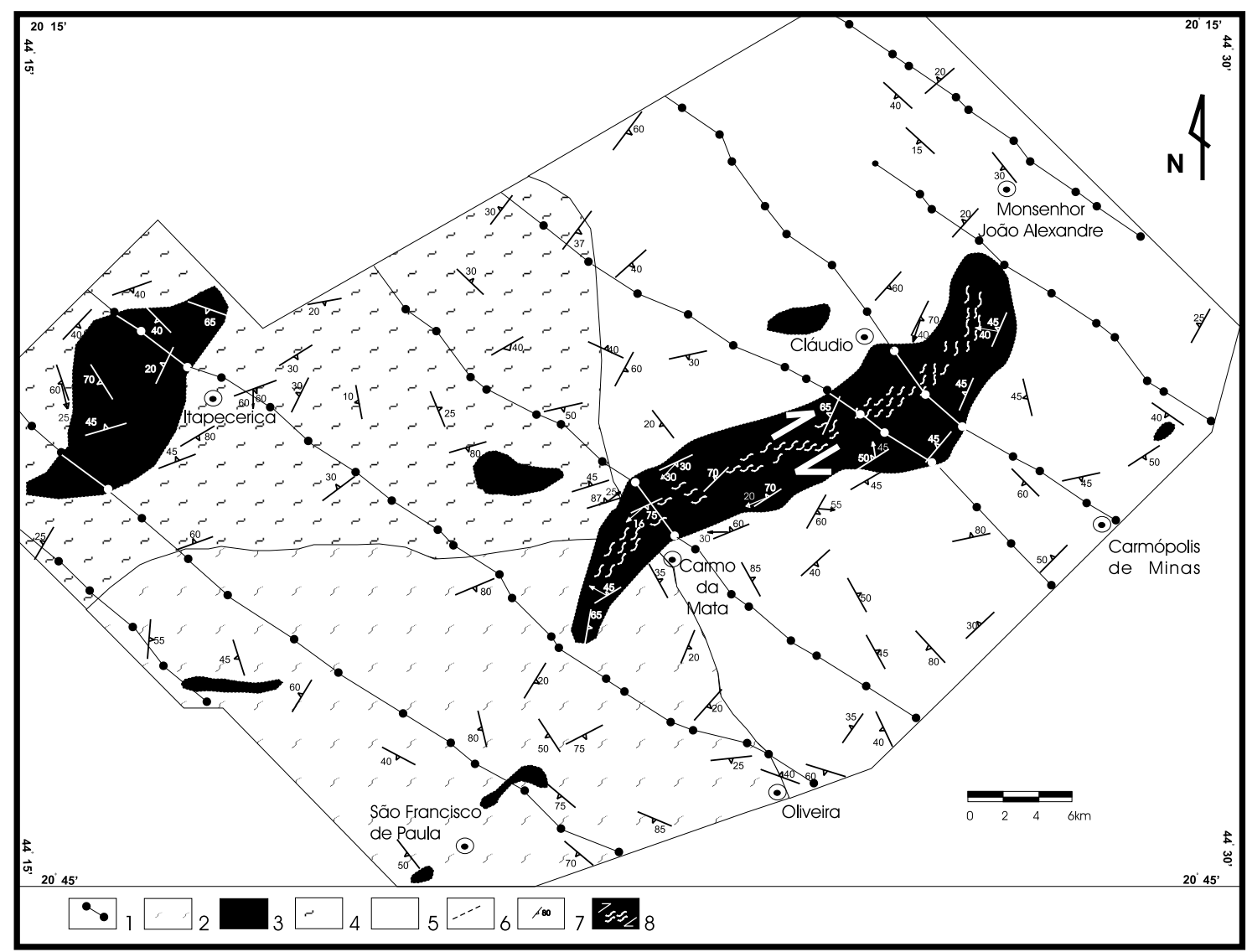

Fig. 2 - Geologic map of the study area (modified from Oliveira 1999), showing the different lithodemic units: 1) Fissure Mafic Unit; 2) Supracrustal Unit; 3) Candeias Gneissic Unit; 4) Itapecerica Gneissic Unit; 5) Cláudio Gneissic Unit; 6) Inferred Contact; 7) Foliation; 8) Cláudio Shear Zone, and 9) Key Outcrops: A - Fernão Dias road; B - Corumbá dimension stone quarry; C - Kinawa dimension stone quarry; D - Morro da antena; E - Vista Bela farm; F - Carmo da Mata dimension stones quarry; G - Marilan dimension stones quarry; H - Lila dimension stones quarry; I - Alemão dimension stones quarry; J - Oliveira dimension stones quarry.

sequences are found, correlated with the Rio das Velhas or Minas Supergroups. The geographic distribution of the Divinópolis Metamorphic Complex, according to (Machado Filho et al. 1983), occurs in the vicinity of Divinópolis, Itaúna, Formiga and Passa Tempo cities (Fig. 1). In the remaining region, rocks from the Barbacena Metamorphic Complex would predominate. However, Teixeira et al. (1996b) consider these two complexes in the Campo Belo region (Fig. 1) as a single unit, naming it Campo Belo Metamorphic Complex. According to Machado Filho et al. (1983), the majority of the lithotypes listed above presents three principal deformation and/or fracturing directions: NS; NW/SE and NE/SW. The tectonic meaning of these directions according to Machado Filho et al. (1983) is the following: 1) NS direction, of more plastic character, would be responsible for the compression of supracrustal sequences in a tight syncline; 2) the NW/SE structures displace the N/S structures and slightly metamorphosed basic dikes were emplaced along this trend; 3) the last direction is related to the generation of the Atlântico Mobile Belt, at the southeastern-eastern margin of the Southern 


\section{TABLE I}

General characteristics of the rocks types of the study area and their probable ages and tectonothermal events.

\begin{tabular}{|c|c|c|c|c|}
\hline Unit & Lithology & $\begin{array}{l}\text { Rock-forming } \\
\text { minerals }\end{array}$ & Ages & $\begin{array}{l}\text { Tectono- } \\
\text { thermal } \\
\text { events }\end{array}$ \\
\hline \multirow[t]{2}{*}{ Fissure Mafic } & gabbronorite & $\begin{array}{l}\text { plagioclase, ortho- and } \\
\text { clinopyroxenes }\end{array}$ & \multirow{2}{*}{$\begin{array}{l}\text { Ages for the } \\
\text { intrusions: } \\
2.658 \mathrm{Ga}^{3} \\
\text { and } 1.875 \mathrm{Ga}^{3} \text {. }\end{array}$} & \multirow[t]{2}{*}{ E4 and E5 } \\
\hline & gabbro & $\begin{array}{l}\text { Plagioclase, } \\
\text { clinopyroxene }\end{array}$ & & \\
\hline \multirow{5}{*}{$\begin{array}{l}\text { Supracrustal Rio } \\
\text { das Velhas } \\
\text { Supergroup }\end{array}$} & $\begin{array}{l}\text { Banded iron } \\
\text { formation }\end{array}$ & $\begin{array}{l}\text { Quartz and } \\
\text { opaque minerals }\end{array}$ & \multirow{5}{*}{$\begin{array}{l}\text { Probable ages } \\
\text { for the mafic- } \\
\text { ultramafic } \\
\text { magmatism, } \\
\text { followed by } \\
\text { sedimentation } \\
\left(2.8 \mathrm{Ga}^{2}\right) \text {. }\end{array}$} & \multirow[t]{5}{*}{$\begin{array}{l}\mathrm{E} 3,(\mathrm{E} 4) ? \\
\text { and E5 }\end{array}$} \\
\hline & quartzite & $\begin{array}{l}\text { Quartz, sillimanite } \\
\text { and garnet }\end{array}$ & & \\
\hline & schist & $\begin{array}{l}\text { Sillimanite, quartz, } \\
\text { mica and garnet }\end{array}$ & & \\
\hline & amphibolite & $\begin{array}{l}\text { Clinoamphibole, } \\
\text { plagioclase and } \\
\text { quartz }\end{array}$ & & \\
\hline & ultramafic & $\begin{array}{l}\text { Orthopyroxene, } \\
\text { olivine, } \\
\text { clinoamphibole }\end{array}$ & & \\
\hline Amphibolitic & amphibolite & $\begin{array}{l}\text { Hornblende, } \\
\text { plagioclase and } \\
\text { quartz }\end{array}$ & $\begin{array}{l}\text { Probable age: } \\
3,38-3,0 \mathrm{Ga}^{1} \\
(?)\end{array}$ & $\begin{array}{l}\text { E1, (E2?), } \\
\text { E3, (E4?) } \\
\text { and E5. }\end{array}$ \\
\hline $\begin{array}{l}\text { Candeias } \\
\text { Gneiss }\end{array}$ & $\begin{array}{l}\text { Gneiss of grano- } \\
\text { dioritic to granitic } \\
\text { composition }\end{array}$ & $\begin{array}{l}\text { Plagioclase, } \\
\text { microcline, quartz } \\
\text { and hypersthene }\end{array}$ & \multirow{3}{*}{$\begin{array}{l}\text { Probable age } \\
\text { for the } \\
\text { protolith } \\
\left(3.38-3.0 \mathrm{Ga}^{1}\right) \\
\text { and probable } \\
\text { age for the } \\
\text { migmatization } \\
\left(2.75-2.72 \mathrm{Ga}^{2}\right) \text {. }\end{array}$} & \multirow[t]{3}{*}{$\begin{array}{l}\text { E1, (E2?), } \\
\text { E3, E4 } \\
\text { and E5 }\end{array}$} \\
\hline $\begin{array}{l}\text { Itapecerica } \\
\text { Gneiss }\end{array}$ & $\begin{array}{l}\text { Gneiss of granitic } \\
\text { composition }\end{array}$ & $\begin{array}{l}\text { Microcline, } \\
\text { plagioclase and } \\
\text { quartz }\end{array}$ & & \\
\hline $\begin{array}{l}\text { Cláudio } \\
\text { Gneiss }\end{array}$ & $\begin{array}{l}\text { Gneiss of grano- } \\
\text { dioritic composition }\end{array}$ & $\begin{array}{l}\text { Plagioclase, } \\
\text { microcline and } \\
\text { quartz }\end{array}$ & & \\
\hline
\end{tabular}

${ }^{1}$ (Teixeira et al. 1996b), ${ }^{1}$ (Teixeira et al. 1998), ${ }^{2}$ (Carneiro et al. 1998b), ${ }^{3}$ (Pinese 1997). 
São Francisco Craton.

\section{GEOLOGY OF THE AREA}

Using satellite imagery and aeromagnetometric map interpretation and by means of regional geologic sections (Oliveira 1999) it was possible to characterize six lithodemic units (Table I and Fig. 2). The older three of these units are gneissic, the fourth is amphibolitic (cannot be mapped at the scale adopted), the fifth is a supracrustal sequence (of greenstone belt type), and the youngest is a mafic dike swarm.

\section{GNEISSIC UNITS}

The petrographic distinction of the gneissic units (Fig. 2) was mainly based on their color and composition. The Cláudio Unit rocks are gray and their composition is predominantly granodioritic. Those from the Itapecerica Unit are light pink and their composition is predominantly granitic. Finally, the Candeias Unit rocks are green and their composition is granitic to granodioritic. The geologic contacts between the gneissic units are masked by the thick weathering mantle and by the superposition of tectonothermal processes taking place since the Mesoarchean. However, the gneissic units have distinct outcrop domains. As an example, the Itapecerica Gneissic Unit, with rocks cropping out in the surroundings of the city it borrows the name from, is characterized by intense migmatization, which imprinted an average mineralogic composition of granitic nature. This migmatization is more pronounced in the western portion of its geographic occurrence. Three pegmatite vein families are associated with the gneissic units. The first family is formed by mobilizates concordant with the gneissic foliation and presents centimetric thicknesses and variable (centimetric to metric) lengths. These mobilizates are essentially composed of feldspars and small quantities of mica. The mobilizates are usually light pink and sometimes white. The second pegmatite family is discordant from the gneissic foliation and is centimetre- to metre-thick, with veins reaching some meters in length. It is in general coarse-grained and light pink, formed by feldspar phenocrysts and less abundant centimetric mica flakes. The third family is represented by pegmatite veins that crosscut either the gneissic foliation or the other two families. These are centimetre-thick and metre-long veins. They are fine- to medium-grained and fill NS-trending fracture planes.

\section{Cláudio Gneissic Unit}

The rocks of this unit crop out in the eastern portion of the study area (Fig. 2) and present granodioritic to dioritic, locally granitic, compositions. They are gray, fine- to medium-grained, banded and migmatized. In some outcrops light pink pegmatitic mobilizates occur, giving a rosy tint to the rock. Regionally, the color of these gneisses can vary, so that eastwards (Fig. 2), it is predominantly gray, diminishing the percentage of light pink felsic mobilizates. The texture of the Cláudio gneisses is predominantly granoblastic to granolepidoblastic. The crystals vary from subidioblastic to idioblastic, medium- to fine-grained, being more rarely coarsegrained. Intergrowth textures are common (e.g. perthite, myrmekite and sometimes antiperthite). In general, plagioclase is the main constituent of these rocks $(30-40 \%)$. The crystals are predominantly medium-grained and those showing polysynthetic twinning vary from subhedral to euhedral. Quartz is in general the second constituent in volume (20$30 \%$ ). The microcline percentage is also variable, sometimes being comparable to the other two constituents. However, it is more common to be subordinated (15-30\%). As varietal mineral, biotite (5$10 \%$ ) shows light to dark or greenish brown pleochroism, altering to chlorite. It has zircon inclusions and sometimes it is associated with opaque minerals. Amphibole (hornblende) is rare and shows greenish pleochroism and can alter to biotite. Opaque minerals, zircon and apatite are accessories, as well as rutile, tourmaline and allanite, which are rarer. As secondary minerals chlorite, sericite, carbonate and epidote occur. 


\section{Itapecerica Gneissic Unit}

The rocks from the Itapecerica Gneissic Unit crop out in the NW portion of the area and present granitic composition, are light pink, migmatized and show inequigranular to equigranular textures and are medium- to fine-grained. In some outcrops closer to the contact with the Candeias Gneissic Unit (Fig. 2), the rocks are greenish. In other localities the gneiss is grayish, as the outcrops located east of Itapecerica city. Pegmatitic or amphibolitic dikes constituting boudins are common features. The texture of the Itapecerica Gneissic Unit rocks is granoblastic to granolepidoblastic with subidioblastic to idioblastic, fine- to medium-grained crystals. Microcline is the predominating mineral (30-40\%), plagioclase second in abundance (15-30\%) and quartz is subordinated to feldspar $( \pm 20 \%)$. Biotite $(<10 \%)$ is a varietal mineral and presents dark brown to greenish pleochroism, locally altering to pale-green chlorite. Amphibole is rarer, fine-grained and alters to biotite. Common accessories are zircon, apatite and opaque minerals. Sericite, chlorite, carbonate and epidote are secondary minerals.

\section{Candeias Gneissic Unit}

The gneisses of this unit crop out in the SW portion of the area (Fig. 2). In the most deformed domains the rocks present granodioritic composition (opdalites). However, in the more homogeneous domains the composition is granitic (charnockites). In general, these rocks are green, slightly migmatized, deformed and medium- to coarse-grained. The mineralogic banding, in some places, is difficult to be observed due to the great homogeneity of the bodies, except for the hyperstene-biotite-gneiss and biotitegneiss where the biotite planar orientation is more enhanced. Close to the contact with the Itapecerica Gneissic Unit, light pink pegmatitic mobilizates are found. The texture of the Candeias-type gneisses varies from granolepidoblastic to granoblastic and they are subdioblastic to idioblastic, predominating granoblastic. Antiperthitic plagioclase (30-45\%) is the main constituent, quartz (20-25\%) and the microcline content (15-20\%) varies from sample to sample but can reach up to $40 \%$. Hyperstene, when present, is medium-grained, has low birefringence and pleochroism varying from light pink to pale green. It alters to amphibole, biotite and chlorite. Biotite, sometimes showing symplectitic intergrowth with quartz, presents light brown, sometimes greenish, pleochroism. In general, this mineral defines the banding of the rock. Locally, biotite alters to chlorite. Opaque minerals, zircon and apatite are the commonest accessories of the rock. Chlorite is the commonest secondary mineral, overgrowing biotite and pyroxene.

\section{Amphibolitic UnIT}

The rocks of this unit are fine-grained, melanocratic, dense, phaneritic, black and strongly foliated. In most places, the amphibolites are found in the form of disrupted thin boudins, representing disrupted and metamorphosed dikes emplaced in the rocks of the gneissic units. The texture of the amphibolites varies from nematoblastic to granolepidonematoblastic. The crystals are fine- to mediumgrained, strongly oriented and altered. Green hornblende $( \pm 50 \%)$, sometimes altered to biotite, is a main mineral. Locally, biotite schist (or biotitite) results from retrograde metamorphism and shearing. Plagioclase is the second constituent in volume (20-30\%). Quartz appears subordinated to the other minerals and its content varies from 5 to $10 \%$ of the rock volume. Biotite, sometimes chloritized, is the product of amphibole transformation. Pale yellow clinopyroxene, present in some rocks, can reach $10 \%$ of the volume and alters to amphibole. Accessory minerals are zircon, opaque minerals and apatite. Besides biotite, secondary minerals are chlorite and amphibole, epidote and sericite.

\section{SUPRACRUSTAL Unit}

Ultramafic rocks (metaperidotite, chlorite-amphibole-schist and hornblendite), amphibolite, garnetsillimanite-schist, garnet-sillimanite-quartzite and 
banded iron formation were characterized in the study area. Regionally, the Supracrustal Unit (Fig. 2) can be correlated with the Rio das Velhas Supergroup, which crops out in the Quadrilátero Ferrífero in Minas Gerais. In some places, they are strongly deformed, metamorphosed and sometimes cataclastic. In the field, the domain of the ultramafic rocks is marked by positive magnetic anomalies as can be observed in aeromagnetometric maps (Oliveira 1999). The metaperidotite is a holocrystalline rock with inequigranular, anhedral to subhedral crystals and grain-size varying from fine to coarse. It shows cumulatic and/or mesh texture. Enstatite makes up $50 \%$ to $60 \%$ of the total volume of the rock. Anhedral clinopyroxene and olivine crystals can reach up to $20 \%$ of the rock volume. The hornblende percentage varies from $20 \%$ to $50 \%$. Spinel can reach $10 \%$ of the rock volume and appears as granular crystals of high relief and color varying from green to greenish-brown. Serpentine, rare in the majority of the thin sections, is found as fibro-lamelar aggregates, resultant from the alteration of olivine and pyroxenes. The opaque minerals can reach 5 to $10 \%$ of the rock. They are isotropic and generally result from spinel transformation. Chlorite is sometimes present as secondary mineral. The chlorite-amphibole-schist is a greenish rock with porphyroblastic texture. Chlorite sums up 30\% of volume and appears as poikilitic porphyroblasts embedded in a fine hornblende mass $( \pm 70 \%)$. A small amount of opaque minerals represents the accessory minerals. The hornblendite is composed of predominantly medium-grained granonematoblastic hornblende crystals $( \pm 95 \%)$ and opaque minerals. The amphibolite is a fine- to medium-grained rock, melanocratic, dense, phaneritic, black and strongly foliated. The amphibolite is, in general, found in contact with ultramafic rocks, mainly in the surroundings of Cláudio, in the supracrustal unit domain (Fig. 2). The main foliation trend is NE/ $\mathrm{SW}$, accompanying the direction of the magnetic anomaly observed in the aeromagnetometric maps (Oliveira 1999). The rock texture varies from nematoblastic to granonematoblastic. The crystals are fine- to medium-grained. Green hornblende $( \pm 40 \%)$, sometimes alters to biotite and chlorite. Plagioclase $( \pm 35 \%)$ is the second constituent in volume and alters to sericite and epidote, and quartz is subordinated $( \pm 10 \%)$. Biotite and clinopyroxene occur occasionally. The main accessories are zircon, opaque minerals and apatite. The garnetsillimanite-schist is a fine- to medium-grained, dark gray, strongly mylonitized magnetic rock. The rock texture varies from granolepidoblastic to granonematoblastic. The crystals vary from subidioblastic to granoblastic. Quartz is the main constituent $( \pm 40 \%)$. The crystals are elongated (ribbons) and follow the rock foliation. Plagioclase $( \pm 15 \%)$ is the second main constituent. Sillimanite in variable proportions (up to 70\%) presents yellow polarization color, is fine- to medium-grained and the crystals are fibrous (more common) or prismatic. It alters to white mica like biotite $( \pm 10 \%)$. Garnet $( \pm 5 \%)$ is a light brown mineral with dark-gray polarization color, almost isotropic with opaque minerals, quartz and white mica inclusions. Opaque minerals, zircon and rutile are the commonest accessories in this rock. Rutile is translucent brown and can be associated with biotite. White mica, epidote and carbonate are secondary minerals, alteration products after plagioclase. White mica is also formed from sillimanite and biotite. The garnetsillimanite-quartzite is a fine-grained rock, pale greenish yellow to white, mylonitized and with subvertical foliation. The texture varies from granolepidoblastic to granonematoblastic and the grain-size varies from fine to medium. Quartz $( \pm 70 \%)$ is the main rock constituent. The crystals are elongated (ribbons) accompanying the foliation. Sillimanite ( $\pm 20 \%)$ presents yellow polarization color, grainsize varying from fine to medium with fibrous crystals (fibrolite) oriented according to the foliation. It alters to white mica. Garnet $( \pm 3 \%)$ is a light brown mineral and has dark gray polarization color. Rare biotite shows light to dark brown pleochroism, is fine-grained, with zircon inclusions, and alters to 
white mica. Opaque minerals, zircon and rutile are common accessories. White mica is the secondary mineral in the rock and it is the alteration product after sillimanite and biotite. Finally, the banded iron formation is a magnetic rock, of predominantly fine grain-size, composed of magnetic minerals and quartz. This rock presents granoblastic texture and the contact between grains is elongated due to deformation. Quartz $( \pm 60 \%)$ is the main constituent of the rock, with elongated crystals in the form of ribbons; it is fine- to medium-grained and strongly recrystallized. Magnetite contents vary from 30 to $40 \%$ in terms of modal composition.

\section{Fissure MAFIC UNIT}

This unit is represented by NW/SE-trending dikes (Fig. 2). These dikes have varied thickness, from metric to dozens of meters and their length can reach dozens of kilometers. The dikes are subvertical and commonly develop ramifications involving the gneissic massifs. Compositionally, the dikes are composed of gabbronorite, gabbro and diabase. The gabbronorite and the gabbro are medium- and coarse-grained, possibly representing variations of crustal emplacement during magmatic crystallization. These rocks are in general dark-colored to greenish, and present massive structure and phaneritic texture. However, when very fine-grained, they can be aphanitic. Along the same lineament small diabase dikes can be observed as a dark, dense and fine-grained rock. The gabbronorite shows ophitic, subophitic to intergranular textures, with subhedral to euhedral crystals, and is medium- to fine-grained. Plagioclase is the most abundant mineral in volume (40-60\%). (Clino- and ortho-) pyroxene contents vary from 20 to $35 \%$ in volume. In general, augite predominates over hyperstene and is predominantly medium-grained, presents variable polarization color (from high to low), the crystals are poikilitic, altering to amphibole. Hyperstene is light pink, pleochroic, from medium- to fine-grained. Hornblende with green pleochroism is the alteration product of pyroxenes (uralitization), reaching up to
$5 \%$ of the rock. Quartz appears in small quantities, with clean, anhedral, fine-grained crystals. Biotite is rare and reddish, pleochroic. Zircon and opaque minerals are accessory minerals. White mica, epidote, carbonate and chlorite are secondary minerals. The gabbro presents ophitic, subophitic or intergranular textures. The medium- to fine-grained crystals vary from subhedral to euhedral. Plagioclase is the most abundant mineral in volume, varying from $30-50 \%$. Augite contents, second component in volume, vary from 20 to $30 \%$. The crystals are poikilitic and alter to amphibole. Hornblende is the uralitization product after pyroxene, being its content in volume variable between 5 and $15 \%$. When present, microcline is rare, showing crosshatch twinning and is associated with myrmekite. Quartz appears in small quantities. Biotite is also rare, reddish and pleochroic. Zircon, opaque minerals and apatite are accessory minerals. White mica, epidote and chlorite are secondary minerals observed in some of the rocks.

\section{METAMORPHISM}

Three distinct and anachronic metamorphic peaks are registered in the rocks of the study area. The first, of highest metamorphic grade related to the granulite facies, is present in the rocks of the Gneissic Units and of the Amphibolitic Unit. The second, predominantly of the amphibolite facies, is observed in the mafic-ultramafic and clastic-pelitic rocks of the Supracrustal Unit. The third is characterized by regional retrograde metamorphic processes that reached the greenschist facies and cover the whole region. The main paragenesis of the Cláudio, Itapecerica and Candeias Gneissic Units is constituted by plagioclase \pm quartz \pm (antiperthitic) microcline \pm amphibole \pm hyperstene \pm biotite. As secondary paragenesis sericite, carbonate, chlorite and epidote occur. Antiperthite and hyperstene indicate that these rocks underwent metamorphic conditions of the granulite facies. On the other hand, the secondary paragenesis indicates greenschist-facies retrograde metamorphism. The Amphibolitic Unit, en- 
closed in these gneissic units, also presents highgrade paragenesis, with the presence of hyperstene, and retrograde metamorphic features of the greenschist facies, characterized by the presence of chlorite. However, Supracrustal Unit rocks show slightly different parageneses. Except for the Supracrustal Unit ultramafic rocks, where green $\mathrm{Al}_{2} \mathrm{O}_{3}$-richer spinels would indicate metamorphic conditions compatible with the amphibolite-granulite facies (Pactunç 1984), the mineral assemblages of the schists (quartz \pm plagioclase \pm sillimanite \pm garnet) and quartzites (quartz \pm sillimanite \pm garnet \pm biotite) indicate that the metamorphism in these rocks reached at most the lower granulite facies. Afterwards, as show the processes of sillimanite alteration to white mica and plagioclase sericitization, these assemblages were re-equilibrated to greenschist facies conditions. However, if in the Supracrustal Unit rocks metamorphism reached the amphibolite or even granulite facies, this was not the case in the Fissure Mafic Unit rocks. These rocks have preserved igneous textures, showing only metamorphic re-equilibration in the greenschist facies that, in fact, is common to all units described in this paper. So, two significant considerations can be expressed: a) the chronostratigraphic character of the Fissure Mafic Unit that, due to its igneous textures and metamorphic parageneses at most of the greenschist facies, indicates their crustal emplacement after the tectonothermal events of higher metamorphic facies that affected the older units; b) the metamorphic facies variation between rocks of the Gneissic, Amphibolitic and the Supracrustal Units. Two hypotheses can be put forward to explain this variation. The first hypothesis would imply in the existence of two tectonothermal events. The first one, of the granulite facies, would be previous to the generation of the Supracrustal Unit rocks and the second one, locally reaching the granulite facies, would follow the generation of the Supracrustal Unit rocks. The second hypothesis would favor the existence of a single event of the granulite facies that occurred after the generation of the Supracrustal Unit rocks. Isotopic evidence supports the first hypothesis (Carneiro et al. 1998b, Teixeira et al. 1996b, Teixeira et al. 1998). These authors, respectively, defend a metamorphic event of the granulite facies in the Mesoarchean and another of amphibolite facies in the Neoarchean (Rio das Velhas Tectonothermal Event). Therefore, it is believed that the first possibility is more realistic to explain the tectonic evolution of the region, according to the reasons exposed in the following items.

\section{STRUCTURAL ANALYSIS}

The rocks of the study region present distinct structural features (Fig. 3, Fig. 4, Table II). For instance, the following features were observed in the supracrustal unit rocks: 1) a mylonitic foliation (Sm) of anastomosing character; 2) structures S/C; 3) S and $\mathrm{Z}$ intrafolial folds, tight and/or isoclinal sheath mesofolds; 4) foliation sigmoids; 5) rotated quartz veins, and 6) tension gashes. The gneissic unit rocks present, besides the structural features described above, the following ones: 7) a gneissic foliation (Sg) of (local) mylonitic character and anastomosing pattern; 8) shear bands $\left(S_{\mathrm{b} 1}\right.$ and $\left.S_{\mathrm{b} 2}\right)$; 9) pegmatitic vein folds and rotated amphibolite boudins. Local normal and reverse faults and a regional megastructure here named Cláudio Shear Zone were characterized. The area also shows intense NW-SEtrending crustal fracturing along which mafic dike swarms were emplaced (Fig. 2).

Foliations - The gneissic foliation (of mylonitic character) presents steep to low-angle dips. This foliation is characterized by a fine compositional banding represented by the orientation of biotite, sericite and amphibole. In general the foliation is anastomosing. The (mylonitic) foliation Sm observed in the supracrustal unit rocks presents steep to lowangle dips and is characterized by the orientation of the following minerals: pyroxene (in the ultramafic rocks); amphibole (in the amphibolites); elongated quartz (ribbons) and sillimanite (in the quartzites); biotite, sericite and sillimanite (in the schists). The structural style and strain of the foliation deformation indicate that they could have originated from 


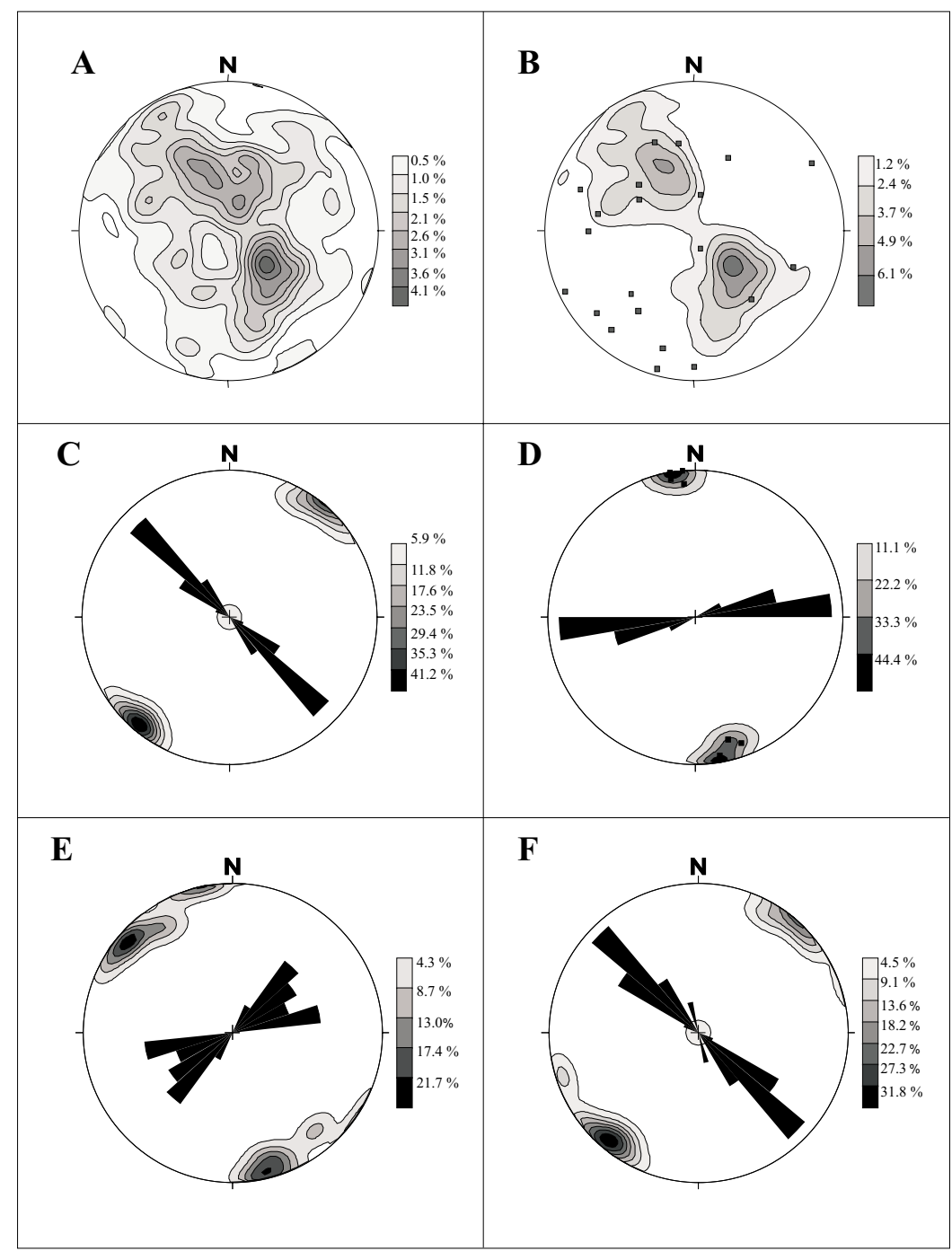

Fig. 3 - Stereographic diagrams representing the polar projections of the foliations of the study area: A) General foliation poles of the area ( $\mathrm{Sg}$ and $\mathrm{Sm}$ ), of NE/SW NS and NW/SE directions. Number of foliation measurements: 388; Maximum: 310/40, 156/40 and 200/37. B) Foliation poles $\mathrm{Sg}$ and $\mathrm{Sm}$ and mineral lineation (filled squares) of the Cláudio Shear Zone domain. Number of foliation measurements: 246; Maximum: 310/40 and 155/40. Number of lineation measurements: 21. C) Poles to foliation of dextral $S_{b 1}$ (Shear bands) of NW/SE direction. Number of foliation measurements: 27; Maximum: 040/82; the rosette represents the foliation direction. D) Poles to foliation of sinistral $\mathrm{S}_{\mathrm{b} 1}$ (Shear bands) of E-W direction. Number of foliation measurements: 22; Maximum: 130/82 and 344/83; the rosette represents the plane direction. E) Poles to foliation of sinistral $\mathrm{S}_{\mathrm{b} 2}$ (Shear bands) of ENE/WSW direction. Number of foliation measurements:17 ; Maximum: 218/88 and 040/85. F) Poles to foliation of dextral $\mathrm{S}_{\mathrm{b} 2}$ (Shear bands) of NW/SE direction. Number of foliation measurements: 9; Maximum: 170/83 and 350/85. 


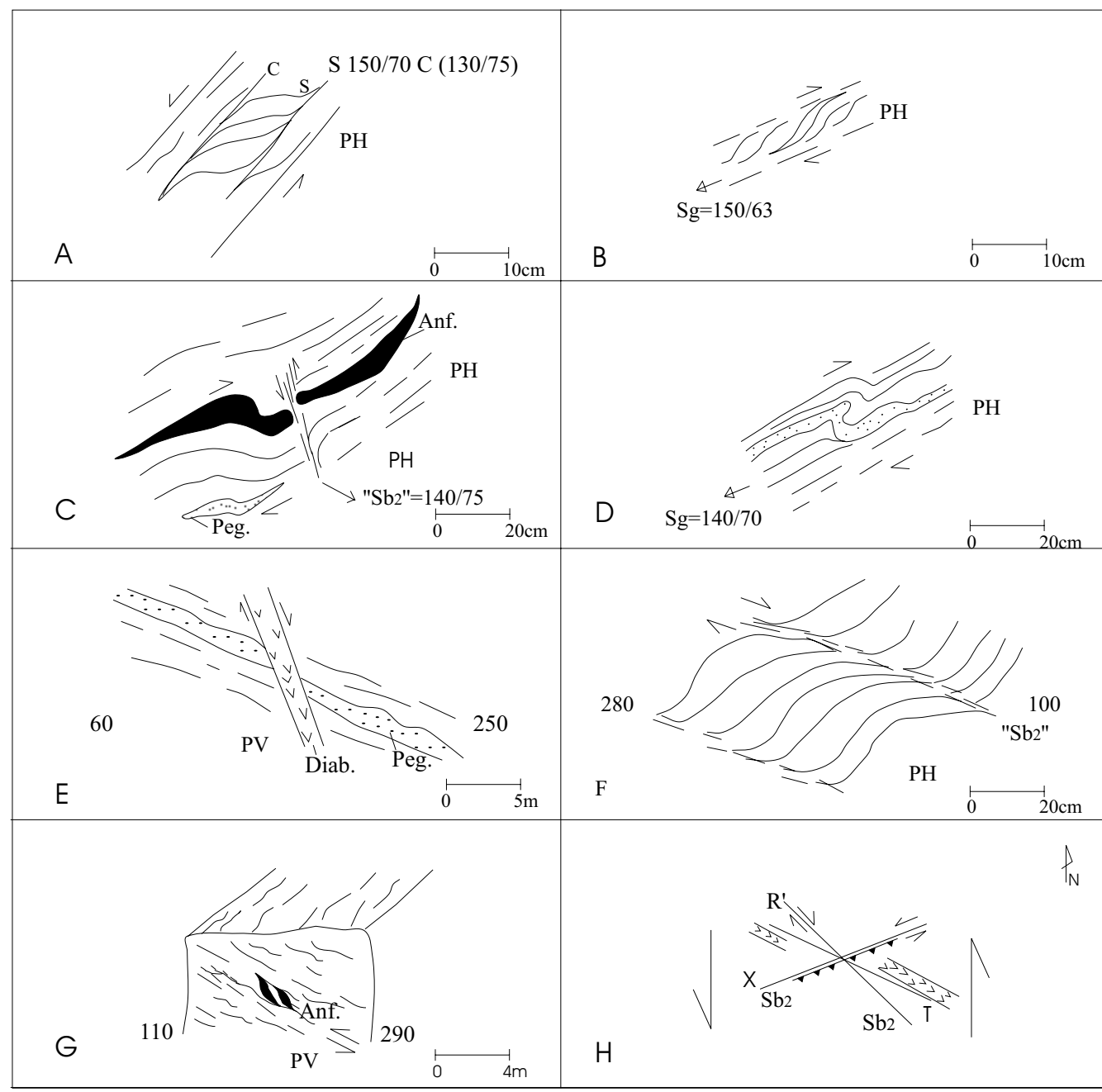

Fig. 4-Kinematic indicators (A-G) and schematic models explaining one of the events active in the study area (H). A) Structure S/C in gneiss of Cláudio Unit, with Event 1 sinistral movement; B) Sigmoidal foliations of the Supracrustal Unit schists with dextral movement; C) Amphibolite boudin rotated clockwise and broken by shear zones (shear bands $\mathrm{Sb}_{2}, \mathrm{X}$ ); D) Asymmetric folded pegmatite vein, Z-shaped, with dextral movement in the gneisses; E) (Brecciated) diabase dike in Cláudio Unit gneisses, displacing pegmatite vein and the gneissic foliation, denoting Event 3 Phase 2 normal movements; F) Shear bands ( $\left.\mathrm{Sb}_{2}, \mathrm{R}^{\prime}\right)$; G) Rotated amphibolite boudins, vertical plane view, with reverse movements; H) Schematic model representing Event 4, sinistral, indicating shear bands $\left(\mathrm{Sb}_{2}\right)$, reverse faults and the intrusion of the Fissure Mafic Unit. Symbology: PH Horizontal plane; PV - Vertical plane; Peg. - Pegmatite; Anf. - Amphibolite; Diab. - Diabase, and R' and $\mathrm{X}$ (anti-Riedel and secondary).

the same deformation phase. Sg and $\mathrm{Sm}$ foliations present inflections along the study area so that the main trend is NE-SW (Figs. 3A and B). Locally, a change in the foliation direction is observed (from
NS to NW-SE). The NW-SE direction predominates over the NS one (Fig. 3A). The lateral relation between these directions can be seen in some key outcrops (points 9A, 9D, 9G, 9I; Fig. 2). At these points 
TABLE II

Simplified table of the structural elements associated with the tectonothermal events.

\begin{tabular}{|c|c|c|c|c|c|}
\hline $\begin{array}{l}\text { Tectono- } \\
\text { thermal }\end{array}$ & Foliation & $\begin{array}{l}\text { Kinematic } \\
\text { indicators }\end{array}$ & $\begin{array}{l}\text { Faults and } \\
\text { shear zones }\end{array}$ & $\begin{array}{l}\text { Metamorphism } \\
\text { (M) }\end{array}$ & $\begin{array}{l}\text { Associated } \\
\text { rocks }\end{array}$ \\
\hline E5 & & & & $\begin{array}{c}\text { M3 } \\
\text { greenschist facies }\end{array}$ & \\
\hline E4 & & $\begin{array}{l}\text { Foliation } \\
\text { sigmoids, } \\
\text { "'shear bands", } \\
\left(\mathrm{Sb}_{2}, \mathrm{R} \text { ' and } \mathrm{X}\right)\end{array}$ & Reverse fault & & $\begin{array}{l}\text { Fissure Mafic } \\
\text { Unit }\end{array}$ \\
\hline E3 & $\begin{array}{l}\text { Gneissic foliation } \\
\text { (of mylonitic } \\
\text { (character or not) } \\
\text { and Sm foliation } \\
\text { (of the Supra- } \\
\text { crustal unit) }\end{array}$ & $\begin{array}{l}\text { “'Z' folds, } \\
\text { foliation, sigmoids, } \\
\text { amphibolite and } \\
\text { rotated and } \\
\text { displaced pegmatite } \\
\text { veins, "shear } \\
\text { bands"' }\left(\mathrm{Sb}_{1}\right)\end{array}$ & $\begin{array}{l}\text { Cláudio Shear } \\
\text { Zone (ZCC) and } \\
\text { normal fault }\end{array}$ & $\begin{array}{c}\text { M2 } \\
\text { Amphibolite } \\
\text { facies } \\
\text { units }\end{array}$ & $\begin{array}{l}\text { Migmatization } \\
\text { and deformation } \\
\text { of the previous }\end{array}$ \\
\hline E2 & (?) & (?) & (?) & (?) & $\begin{array}{l}\text { Mafic-ultramafic } \\
\text { magmatism and } \\
\text { sedimentation of } \\
\text { the Supracrustal } \\
\text { Unit }\end{array}$ \\
\hline E1 & $\begin{array}{l}\text { Gneissic foliation } \\
\text { (?), fold with } \\
\text { double vergence } \\
\text { and S/C }\end{array}$ & $\begin{array}{l}\text { "S' and sheath } \\
\text { folds, S/C } \\
\text { structures }\end{array}$ & (?) & $\begin{array}{c}\text { M1 } \\
\text { Granulite } \\
\text { facies }\end{array}$ & $\begin{array}{l}\text { Formation of the } \\
\text { protolith of the } \\
\text { Gneissic and } \\
\text { Amphibolitic } \\
\text { Units }\end{array}$ \\
\hline
\end{tabular}

the predominant foliation (NE-SW) is folded and its trajectory in folds inflects to NS and NW-SE. The last trend represents one of flanks of folds of 2 to 3 meters of amplitude. Thus the several trends characterized in the region as a whole reflect the principal foliation inflection (NE/SW). In general the foliation dip is steep $\left(70^{\circ}\right.$ to $\left.80^{\circ}\right)$, mainly along the Cláudio Shear Zone (Fig. 2). However, outside the Cláudio Shear Zone domain medium to low-angle dips $\left(50^{\circ}\right.$ to $\left.20^{\circ}\right)$ are observed. The mineral lineation $\left(l_{\mathrm{m}}\right)$ also presents a certain variation: from strike (Kinawa quarry, point 9C, Fig. 2) to oblique (Corumbá quarry, point 9B; Fig 2) and dip (in the quartzites, point 9D). In these three cases, the foliation planes present NE-SW trends.
Shear bands - Shear bands $S_{b 1}$ and $S_{b 2}$ are subvertical and displace the foliation of the gneissic units, as seen in horizontal and vertical planes of the quarries of the region. The foliation $\mathrm{S}_{\mathrm{b} 1}$ is oriented according to NW/SE and E-W trends (Figs. 3C and D) and pegmatitic mobilizates intrude along the foliation planes. The NW/SE trend presents a dextral kinematic component whereas the E-W trend has a sinistral component (seen on the horizontal plane). Foliation $S_{\mathrm{b} 2}$ is oriented along ENE/WSW and NW/SE trends (Figs. 3E and F). $\mathrm{S}_{\mathrm{b} 2}$ does not present pegmatitic mobilizates along its planes. The kinematics of the ENE/WSW foliation has a sinistral component and that of the NW/SE plane a dextral component (seen on the horizontal plane). These 
two foliations were interpreted as a pair R' and $\mathrm{X}$ (anti-Riedel and secondary, Fig. 4H, Sanderson and Marchini 1984). Shear bands $S_{b 1}$ and $S_{b 2}$ are different in the following aspects: the first group presents pegmatitic mobilizates along its planes, lacking in the second group. Besides, the kinematic trends of both groups are opposite (Figs. 3C; 3D; 3E and 3F).

Structures S/C - Structures S/C [S150/70 C(130/ 75), seen in the horizontal plane AC] can be observed at restricted points in the area (points $9 \mathrm{C}$ and 9B; Fig 2). Their dimensions are centimetric and the kinematics indicate sinistral movements (Figs 4A).

Folds - Folds are observed locally and can be described as: intrafolial and tight, with $\mathrm{S}$ and $\mathrm{Z}$ asymmetries; sheath mesofolds (rare) and tight and/or isoclinal symmetric (with flanks inverted or not). The most common folds have $\mathrm{S}$ and $\mathrm{Z}$ asymmetries (the latter being more prominent). The $\mathrm{S}$ and $\mathrm{Z}$ intrafolial folds are important in the characterization of two of the phases of tectonic evolution of the study area.

Foliation Sigmoids - Foliation Sigmoids are observed both in schists and gneisses and characterize movements with dextral directional components (seen on the AC plane), where the foliation dip is steep and of high strain [e.g. 130/80 $\left(1_{\mathrm{m}}=\right.$ 225/40)]. Locally, sigmoids indicative of normal movements with an oblique component are observed (seen on vertical AC plane).

Pegmatites - In the gneissic unit domain Z-folded pegmatitic mobilizates are observed indicating dextral movement seen on the AC plane. Locally appear veins denoting normal movements.

Quartz Veins - Both in the supracrustal unit rocks and the gneissic unit domains, rotated centimetric quartz veins are observed. These veins indicate dextral movement, seen on the AC plane. Locally, veins indicating reverse movement occur.

Amphibolite Boudins - In the domains of the three gneissic units centimetric to metric amphibolite boudins occur disrupted, strongly deformed and rotated, in general showing dextral movement. Lo- cally there are boudins indicating sinistral movement.

Faults - Faulting systems can be observed in several key outcrops (points 9A, 9C, 9D, 9G, 9H and 9J; Fig. 2). At the sides of the Fernão Dias highway, a NW/SE fault plane is intruded by volcanic material that precedes or is coeval to the fault generation, appearing as a breccia. The fault plane cuts the gneissic banding, is subvertical and displaces pegmatite veins, indicating normal movement (Fig. 4E). In the Montueira Ridge, close to Carmópolis de Minas, a fault with the same trend is observed, yielding a steep slope. The reverse faulting of local nature does not present regional correlation of major magnitude. The indicators for this movement are the (sinistral) $\mathrm{S}_{\mathrm{b} 2}$ foliation, seen in the vertical plane, and the foliation sigmoids seen in the gneisses, schists and quartzites.

Finally, the mega-structure that characterizes the Cláudio Shear Zone, firstly revealed by aeromagnetometric images (Oliveira 1999), describes a roughly NE-SW alignment (Fig. 2). Along the Cláudio Shear Zone are observed migmatized gneisses, ultramafites, amphibolites, quartzites and schists showing high strain. The foliation inside the mega-structure shows medium- to high-angle dips and mylonitic character. Its fabric describes NE/SW (Fig. 3B) and subordinately NS and NW/SE trajectories (Fig. 3A), characterizing regional folding. The general fabric is represented by " $S$ ' tectonites composed of pegmatitic mobilizates concordant with the foliation. Other features presented by this mega-structure are: $\mathrm{Z}$ intrafolial folds, foliation sigmoids, amphibolite boudins, pegmatite and rotated quartz veins with dextral movement. The meaning of the variation of the different (strike, oblique or dip) mineral lineation trends, contained in the foliation planes is still an open issue in the regional context.

\section{TECTONIC EVOLUTION}

It is known that the period between 3.6 and 2.5 $\mathrm{Ga}$ was responsible for the worldwide formation of 
granite-greenstone terranes, with their apex around 3.0-2.6 Ga (e.g. Byerly et al. 1996, Collerson and Macdonald 1998, Friend et al. 1996, Goodwin 1991, Hamilton et al. 1979, Hamilton 1998, Kröner et al. 1996, Myers 1993, Sarkar et al. 1993, Tankard et al. 1982, Windley 1976, Worden et al. 1995). In the case of the southern São Francisco Craton, it was in the Neoarchean (from 2.78 to $2.70 \mathrm{Ga}$ ) that this crustal segment had its main accretion stage and crustal reworking (e.g. Carneiro et al. 1998a, Machado et al. 1996, Noce 1995). Considering that in the southwestern portion of the study area in the Campo Belo region the gneissic units present zircon $\mathrm{U}-\mathrm{Pb}$ ages of the order of $3.2 \mathrm{Ga}$ (Teixeira et al. 1996a, Teixeira et al. 1998), it is possible to infer that the beginning of the crustal evolution of the studied segment started in the Mesoarchean. Thus, on a primordial sialic crust formed by the protoliths of the gneissic and amphibolitic units, a tectonothermal event took place, preserving some kinematic and petrologic records that characterize Event 1.

Event 1 - It is the oldest event or the event that was not totally obliterated by the successive events imprinted in the rocks of the study region. Its deformational structures are foliations of S/C-type, sinistral-rotated amphibolitic boudins and centimetric intrafolial $\mathrm{S}$ folds that are observed locally (Fig. 4). Systematically, the rocks that were affected by this event have relic parageneses of the granulite facies. Later migmatization processes related to Event 3 developed on this fabric.

Event 2 - Similarly to the Quadrilátero Ferrífero, where the Rio das Velhas Supergroup crops out, the study area also presents remmants of the greenstonebelt type supracrustal sequences, with ultramafic and clastic-pelitic rocks (Fig. 2). In the case of the Quadrilátero Ferrífero, Carneiro et al. (1998b) consider that the sedimentation and magmatism responsible for the formation of the Rio das Velhas Supergroup rocks would be in operation around 2.8 $\mathrm{Ga}$, in an ensialic-type basin. This would be, in principle, the situation of the study area where, during
Event 2, of essentially extensional characteristics, the ensialic basin would be installed for sedimentation and magmatism of the Supracrustal Unit (or Rio das Velhas Supergroup).

Event 3 - As said before, it was between 2.78 and $2.70 \mathrm{Ga}$ that in the Southern São Francisco Craton the main accretion and crustal reworking phase took place (e.g. Carneiro et al. 1998a,b, Machado et al. 1996, Noce 1995). This evolution was related to the Rio das Velhas Tectonothermal Event. The peak of this event occurred around 2.78-2.77 Ga (Carneiro et al. 1998b, Machado and Carneiro 1992), when the zircons of the Alberto Flores Gneiss from the Bonfim Metamorphic Complex suffered overgrowing, indicating isotopic re-equilibration under high amphibolite metamorphic facies conditions. These metamorphic conditions have correspondence in the study region, where an ample and vigorous migmatization process is observed, imposed on the rock fabric generated during Event 1. In structural terms, the migmatitic rocks originated during this process present the same kinematic elements of the Supracrustal Unit rocks. Two important considerations derived from this fact: a) migmatization follows the Supracrustal Unit sedimentation and magmatism; b) due to the tectonic intensity of this process, the presence of high amphibolite or granulite facies parageneses, common in the Supracrustal Unit rocks of the study region but lacking in the Quadrilátero Ferrífero Archean supracrustal rocks, would be explained. In hierarchic terms, Event 3 can be divided in two phases. To Phase 1 would correspond the migmatization process and the structural elements mainly found in the Cláudio Shear Zone (Fig. 2), which are: asymmetric $Z$ folds, foliation sigmoids, pegmatitic vein folds and rotated amphibolite boudins indicating dextral movement. Associated with the final phase of this dextral directional flow brittle-ductile shear zones are observed, here represented by $S_{b 1}$ foliations (shear bands, Figs. 3C and 3D), associated with pegmatitic mobilizates. $\mathrm{NW} / \mathrm{SE}$ - trending $\mathrm{S}_{\mathrm{b} 1}$ presents a dextral component and the less conspicuous E/W - trending $S_{\mathrm{b} 1}$ has a 
sinistral component. To Event 3, Phase 2 would correspond a crustal relaxation phase with the generation of faults with normal movement, observed in the Supracrustal Unit quartzites that crop out south of Cláudio and in the gneissic rocks at the sides of the Fernão Dias highway, north of Carmópolis de Minas. The lineation contained by the foliation planes is steep (parallel to the dip to slightly oblique) and the kinematic indicators associated with this phase are rotated pegmatite veins and fault planes containing volcanic material breccia (Fig. 4G). This phase is not expressive, does not obliterate the previous one and its kinematics do not have regional significance.

Event 4-The initial phase of this event had a brittleductile flow character, and produced $\mathrm{S}_{\mathrm{b} 2}$ foliations (shear bands, Figs. 3E and 3F), forming a pair R' and $X\left(R^{\prime}\right.$ anti-riedel and secondary, Fig. 4H) of NE/SW and NW/SE directions and high-angle dips. These foliations crosscut the mylonitic gneissic foliation (points 9B, 9C, 9F, 9G and 9H; Fig 2). Seen on the XZ plane, these foliations indicate reverse movements. With the final phase the emplacement of the $2.658 \mathrm{Ga}$ old, NW/SE-trending fissure mafic magmatism could be correlated (e.g. Pinese et al. 1995, Pinese 1997) and the $2.612 \mathrm{Ga}$ granitic magmatism, interpreted as the final stage of the Archean platform consolidation (Noce 1995). Regionally this event can be correlated to the Rio das Velhas Event 2, with sinistral component (Endo 1997).

Event 5 - The fifth event is a regional metamorphic re-equilibration to the greenschist facies, later than the fissure mafic magmatism. Lacking more precise chronostratigraphic indicators to limit its minimum age, it is suggested that Event 5 be of Transamazonian age or younger.

\section{CONCLUSIONS}

From the geologic results discussed above and geochronologic data of the southern São Francisco Craton, the following conclusions can be formulated: 1) the protoliths of the gneisses from the three lithodemic units and the amphibolitic unit were emplaced in the crust in the Mesoarchean and reworked in this period and mainly in the Neoarchean; 2) the volcano-sedimentary sequence of the supracrustal unit was deposited before Event 3, which is the main migmatization event in the area; 3 ) the main deformational events in the area essentially occurred in the Neoarchean. This conclusion is based on $\mathrm{Sm}-\mathrm{Nd}$ geochronologic data (Pinese 1997), obtained from dikes of gabbronoritic composition that crystallized $2,658 \pm 44 \mathrm{Ma}$ ago. These dikes are not deformed and only present the original magmatic paragenesis re-equilibrated to the greenschist facies. Thus, as in the study area, similar dikes are found intrusive in the gneissic and supracrustal units that have relic high-grade metamorphic parageneses, showing that the fissure mafic unit was a placed in the crust after the main Archean tectonothermal events of the Campo Belo Metamorphic Complex.

\section{ACKNOWLEDGEMENTS}

The authors wish to thank FONTEX/SA - Ornamental Rocks Mining Company and FAPEMIG (CRA-827/97; 2220/96) for the financial support during field work; Drs. Issamu Endo, Hermínio A. Nalini Júnior, Mônica Heilbron and Caroline J. Sousa for careful reading and suggestions to this work; CAPES for the M.Sc. scholarship and two anonymous reviewers for their valuable comments and suggestions.

\section{RESUMO}

Estudos geológicos sistemáticos permitiram a caracterização de seis unidades litodêmicas na área estudada: três gnáissicas, uma anfibolítica, uma supracrustal e uma máfica fissural. A assembléia mineral e os registros estruturais dessas unidades litodêmicas mostraram que a área estudada foi afetada por cinco eventos tectonotermais. O padrão estrutural do primeiro e último evento ocorreu em condições de fácies granulito e revelaram uma cinemática essencialmente sinistral. O segundo evento mostrou uma tectônica extensional relacionado à abertura da bacia ensiálica onde se alojou a seqüência vulcanosedimentar da 
unidade supracrustal. O terceiro evento, que é o mais expressivo na região estudada, é o responsável por um intenso processo de migmatização regional e pela geração da Zona de Cisalhamento Cláudio (de cinemática dextral). O quarto evento é representado por um magmatismo máfico fissural (provavelmente dois tipos diferentes de enxames de diques máficos) e, finalmente o quinto evento é um retrometamorfismo regional que atingiu a fácies xisto verde, finalizando os principais processos de evolução tectônica do Complexo Metamórfico Campo Belo.

Palavras-chave: Cráton, Arqueano, evolução tectônica, unidades litodêmicas, Complexo Metamórfico.

\section{REFERENCES}

Alkmim FF, Brito Neves BB And Alves JAC. 1993. Arcabouço tectônico do Cráton São Francisco - Uma revisão. In: Simpósio SOBRE o CRÁton do SÃo Francisco, 1., Salvador. Anais..., Salvador, 1993. p. $45-62$.

Almeida FFM DE. 1977. O Cráton São Francisco. Rev Bras Geo 7: 349-364.

Byerly GR, Kröner A, LOWE DR, TODT W AND WALSH MM. 1996. Prolonged magmatism and time constraints for sediment deposition in the early Archean Barberton greenstone belt: evidence from the Upper Onverwacht and Figura Tree groups. Precam Research 78: 125-138.

Carneiro MA, Teixeira W, Nalini Júnior A, OliVEIRA AH DE AND CARvalho JÚNior IM DE. 1996a. Archean ultramafic-mafic magmatism in the southern São Francisco Craton Campo Belo Complex): Preliminary petrographic and geochemical results. In: Simpósio de Terrenos Arqueanos da Plataforma Sul-Americana, Brasília. Anais..., Brasília, 1996. p. 32-33.

Carneiro MA, Teixeira W, Noce CM and FernanDES RA. 1996b. Archean growth processes in the Quadrilátero Ferrífero: A geochronological U-Pb and Sm-Nd approach to the Rio das Velhas Event (2780-2700 Ma). In: Simpósio de Terrenos ArQueanos da Plataforma Sul-Americana, Brasília. Anais..., Brasília, 1996. p. 59-60.
Carneiro MA, Teixeira W, Carvalho Júnior IM de, Oliveira AH de And Fernandes RA. 1997a. Archean Sm/Nd isochron age from the Ribeirão dos Motas layered rocks sequence, southern São Francisco Craton, Brazil. In: South-American SymPosium on Isotope Geology, Campos do Jordão. Anais..., Campos do Jordão, 1997. p. 63-64.

Carneiro MA, Teixeira W, Nalini Júnior HA, Carvalho Júnior IM de, Oliveira AH de, FernanDES RA AND Moutte J. 1997b. A seqüência acamadada de Ribeirão dos Motas. In: Simpósio SulAmericano de Geologia Isotópica, Campos do Jordão, Guia de excursões..., Campos do Jordão, 1997. p. 83-86.

Carneiro MA, Carvalho Júnior IM de, Fernandes RA AND Teixeira W. 1997c. Geologia da parte do segmento crustal situado entre as cidades de Oliveira, Campo Belo e Santana do Jacaré, MG. In: Simpósio de Geologia de Minas Gerais, 9., Ouro Preto. Boletim..., Ouro Preto, 1999. p. 36-37.

Carneiro MA, Carvalho Júnior IM de and Teixeira W. 1998a. Petrologia, Geoquímica e Geocronologia dos diques máficos do Complexo Metamórfico Bonfim Setentrional (Quadrilátero Ferrífero) e suas implicações na evolução crustal do Craton do São Francisco Meridional. Rev Bras Geo 28(1): 29-44.

Carneiro MA, Carvalho Júnior IM de and Teixeira W. 1998b. Ensialic tectonic setting of the archeaen Rio das Velhas greenstone belt: $\mathrm{Nd}$ and $\mathrm{Pb}$ isotopic evidence from the Bonfim Metamorphic Complex, Quadrilatero Ferrífero, Brasil. Rev Bras Geo 28(2): 189-200.

Carvalho Júnior IM de, Carneiro MA, Suita MT de F And Teixeira W. 1997. Anfibólio intercúmulus na seqüência acamadada do Ribeirão dos Motas: um modelo petrogenético para sua origem. In: SıMPósio de Geologia de Minas Gerais, 9., Ouro Preto. Anais..., Ouro Preto, 1997. p. 38-39.

Carvalho Júnior IM de, Carneiro MA, Nalini Júnior HA AND TeIXeira W. 1998. Seriam as rochas da seqüência acamadada de Ribeirão dos Motas o correspondente plutônico do magmatismo ultramáfico do Greestone Belt Rio das Velhas? In: CoNgresso Brasileiro de Geologia, 40., Belo Hori- 
zonte. Anais..., Belo Horizonte, 1998. p. 67.

Collerson KD and MacDonald GD. 1998. Crustal evolution of the north Australian Craton: A Review of field, tectonic, isotopc and metallogenic constraints. In: INTERNATIONAL CONFERENCE ON Basement Tectonics, 14., Ouro Preto. Anais..., Ouro Preto, 1998. p. 96-101.

CorrêA da Costa PC. 1999. Episódios de formação de crosta continental arqueana no Cráton do São Francisco Meridional: Um exemplo a partir da região de Candeias - Campo Belo, MG. Unpublished MSc. Thesis, DEGEO/UFOP, Fed. Univ. of Ouro Preto, 132 p.

Corrêa da Costa PC, Carneiro MA and Nalini JÚNIOR HA. 1998. Quartzitos da região de Candeias - Campo Belo: Metassedimentos do Supergrupo Rio das Velhas ou do Supergrupo Minas? In: Congresso Brasileiro de Geologia, 40., Belo Horizonte. Anais..., Belo Horizonte, 1998. p.8.

Endo I. 1997. Regimes Tectônicos do Arqueano e Proterozóico no Interior da Placa Sanfranciscana: Quadrilátero Ferrífero e Áreas adjacentes, Minas Gerais. Unpublished PhD Thesis, Inst. of Geosciences/USP, Univ. of São Paulo, 243 p.

Fernandes RA AND CARneiro MA. 2001. O complexo metamórfico Campo Belo (Cráton São Francisco Meridional): unidades litodêmicas e evolução tectônica. Rev Bras Geo, in press.

Fernandes RA, Carneiro MA and Teixeira W. 1997. O metamorfismo das rochas da região de Santana do Jacaré, MG. In: Simpósio de Geologia de Minas Gerais, 9., Ouro Preto. Anais..., Ouro Preto, 1997. p. $45-46$.

Fernandes RA, Carneiro MA, Carvalho Júnior IM de, Carneiro MA, Teixeira W and Nalini Júnior HA. 1998. Eventos de superimposição metamórfica nas rochas do Complexo Metamórfico de Campo Belo. In: Congresso Brasileiro de Geologia, 40., Belo Horizonte. Anais..., Belo Horizonte, 1998. p. 58 .

Friend CRL, NutMan AP, BaAdsgaARd H, KinNy PD AND MCGREgOR VR. 1996. Timing of late archeas terrane assembly, crustal thickening and granite em- placement in the Nuuk region, southern West Greenland. Earth and Planetary Sci Letters 142: 353-365.

GoodwIN AM. 1991. Precambrian Geology. London: Acad Press, p. 666.

Hamilton WB. 1998. Archean Tectonics and Magmatism. International Geology Review 40: 1-39.

Hamilton PJ, Evensen NM, O’Nions RK, Smith HS AND ErLanK AJ. 1979. Sm-Nd dating of Onverwacht Group volcanics, Southern Africa. Nature 279: 298300.

Kröner A, Hegner E, Wendt JI And Byerly GR. 1996. The oldest part of the Barberton granitoidgreenstone terrain, South Africa: evidence for crust formation between 3.5 and $3.7 \mathrm{Ga}$. Precam Research 78: $105-124$.

Machado Filho L, Ribeiro MW, Gonzalez SR, Schenini CA, Santos Neto AS, Barros Palmeira RC, Pires JL, Teixeira W and Castro HEF. 1983. Geologia. In: Projeto Radambrasil, Folhas SF.23/24 Rio de Janeiro/Vitória 32: 36-45.

Machado N and Carneiro MA. 1992. U-Pb evidence of Late Archean tectonothermal activity in southern São Francisco shield, Brazil. Can J of Earth Sci 29: 2341-2346

Machado N, Schrank A, Noce CM and Gauthier G. 1996. Ages of detrital zircon from ArchaeanPaleoproterozoic sequences: Implications for Grenstone Belt setting and evolucion of a Transamazonian foreland basin in Quadrilátero Ferrífero, southeast Brazil. Earth and Planet Sci Letters 141(1-4): 259 276.

Myers JS. 1993. Precambrian History of the west Australian Craton and adjacent orogens. Annu Ver Earth Planet Sci 21: 453-485.

Noce CM. 1995. Geocronologia dos eventos magmáticos, sedimentares e metamórficos na região do Quadrilátero Ferrífero, Minas Gerais. Unpublished $\mathrm{PhD}$ Thesis, Inst. of Geosciences/USP, Univ. of São Paulo, 128 p.

Oliveira AH DE. 1999. Evolução tectônica de um segmento crustal Arqueano do Cráton São Francisco Meridional. Unpublished MSc. Thesis, DEGEO/ 
UFOP, Fed. Univ. of Ouro Preto, 104 p.

Oliveira AH de and Carneiro MA. 1999. Petrografia do Complexo Metamórfico Campo Belo e das Unidades Supracrustais de um segmento siálico do Cráton São Francisco Meridional. In: ANAIS DO $7^{\circ}$ Simpósio de Geologia do Centro-Oeste e $10^{\circ}$ Simpósio de Geologia de Minas Gerais, 10., Brasília. Anais..., Brasília, 1999. p. 5

Oliveira AH de, Carneiro MA and Nalini JÚnior HA. 1998a. Compartimentação litoestrutural de um segmento crustal arqueano do Cráton São Francisco Meridional. In: Congresso Brasileiro de GeoloGIA, 40., Belo Horizonte. Anais..., Belo Horizonte, 1998. p. 54.

Oliveira AH de, Corrêa da Costa PCC, Carneiro MA AND Nalini Junior HA. 1998b. Feições Lineares e suas implicações em um segmento crustal Arqueano do Cráton São Francisco Meridional. In: Congresso Brasileiro de Geologia, 40., Belo Horizonte. Anais..., Belo Horizonte, 1998. p.58.

Oliveira AH de, Carneiro MA and Endo I. 1999. Evolução tectônica de um segmento crustal Arqueano do Cráton São Francisco Meridional. In: ANAIS do $7^{\circ}$ Simpósio de Geologia do Centro-Oeste e $10^{\circ}$ Simpósio de Geologia de Minas Gerais, 10., Brasília. Anais..., Brasília, 1999. p. 73.

Pactunç AD. 1984. Metamorphism of the Ultramafic Rocks of the Thompson Mine, Thompson Nickel Belt, Northeern Manitoba. Can Mineralogist 22: 7791.

PINESe JPP. 1997. Geoquímica, Geologia Isotópica e Aspectos Petrológicos dos Diques Máficos Pré-Cambrianos da Região de Lavras (MG) Porção Sul do Cráton São Francisco. Unpublished PhD Thesis, Inst. of Geosciences/USP, Univ. of São Paulo, 178 p.

Pinese JPP, Teixeira W, Piccirillo EM, Queménéur JJG and Bellieni G. 1995. The Precambrian Lavras mafic dykes, southern São Francisco Craton, Brazil: preliminary geochemical and geochronological results. In: Baer G and Heimann A (eds); Physics and chemistry of dykes. Rotterdam: Balkema, p. 205-218.

SANDERSON DJ AND Marchini WRD. 1984. Transpres- sion. Journ. of Struct. Geol. 6(5): 449-458.

Sarkar G, Corfu F, Paul DK, Mcnaughton NJ, Gupta SN AND BishUI PK. 1993. Early Archean crust in Bastar Craton, Central India-geochemical and isotopic study. Precam Research 62: 127-137.

TANKARD AJ, JaCKSON MPA, ERICKSSON KA, HobDaY DK, Hunter DR AND Minter WEL. 1982. Crustal evolution of southern Africa. New York: Springer Verlag, p. 523.

Teixeira W. 1993. Avaliação do acervo de dados Geocronológicos e isotópicos do Cráton do São Francisco - Implicações Tectônicas. In: Simpósıo sobre o Cráton do SÃo Francisco, 1., Salvador. Anais..., Salvador, 1993. p. 11-33.

Teixeira W and Canzian FS. 1994. A Evolução tectonotermal Proterozóica do Cráton do São Francisco com base em interpretações geocronológicas $\mathrm{K}$-Ar em rochas de seu embasamento. Boletim IGUSP 25: $61-80$

Teixeira W and Silva FC. 1993. A evolução tectonotermal proterozóica do Cráton do São Francisco, com base em interpretações geocronológicas K-Ar. In: Simpósio SObRe o CRÁton do SÃo FranCISCO, 2., Salvador. Anais..., Salvador, 1993. p. 1820.

Teixeira W, Carneiro Ma, Noce CM, Machado N, Sato K and Taylor PN. 1996a. Pb, Sr and Nd isotope constraints on the Archean evolution of gneissicgranitoid complexes in the southern São Francisco Craton, Brazil. Precam Reasearch 78: 151-164.

Teixeira W, Cordani UG, Nutman AP and Sato K. 1996b. Polyphase crustal evolution in the late Archean: The case of the Campo Belo Metamorphic Complex, In: Simpósio de Terrenos Arqueanos da Plataforma Sul-Americana, Brasília. Anais..., Brasília, 1996. p. 63-64.

Teixeira W, Onstott TC, Makenya M and Szabó GAJ. 1997. Proterozoic Thermochronology implications from ${ }^{40} \mathrm{Ar} /{ }^{39} \mathrm{Ar}$ and $\mathrm{K}$-Ar dating of the Campo Belo Metamorphic Complex, Southern São Francisco Craton. Brasil. An Acad Bras Ci 69(1): 559-575.

Teixeira W, Cordani UG, Nutman AP and Sato K. 
1998. Polyphase Archean evolution in the Campo Belo Metamorphic Complex, Southern São Francisco Craton, Brasil: SHRIMP U-Pb zircon evidence. J South American Sci 11: 279-289.

Teixeira W, Carneiro MA, Queménéur JJ, Pinese JP AND Oliveira AH DE. 1999. A história policíclica arqueana e paleoproterozóica do cinturão granulítico meridional do Cráton São Francisco. In: ANAIS do $7^{\circ}$ Simpósio de Geologia do Centro-Oeste e $10^{\circ}$ Simpósio de Geologia de Minas Gerais, 10., Brasília. Anais..., Brasília, 1999. p. 8
WIndLey BF. 1976. The early history of the Earth. New York: John Wiley \& Sons, p. 526.

Worden JM, Cumming GL and Krstic D. 1995. The sequence of magmatic and mineralization events in the Abitibi greenstone belt: isotopic evidence from Taylor Township, Timmins area, northern Ontario, Canada. Can J Earth Sci 32: 1221-1235. 